\title{
URBAN REVITALISATION FOR A CITY'S SOUL: THE CASE OF KAMPONG BHARU
}

\section{Halimaton Saadiah Hashim ${ }^{1,2,3^{*}}$, Sarah Aziz ${ }^{2}$ and Nik Mohd Ruiz Razy ${ }^{3}$}

${ }^{1}$ Selangor Town and Country Planning Department (Previous), Shah Alam, Selangor, MALAYSIA

${ }^{2}$ Institute for Environment and Development (LESTARI), Universiti Kebangsaan Malaysia, MALAYSIA

${ }^{3}$ Rekarancang Sdn. Bhd., Planning and Development Consultants, Kuala Lumpur, MALAYSIA

*Corresponding author: halimaton.s.hashim@gmail.com

Published online: 29 December 2017

To cite this article: Halimaton Saadiah Hashim, Sarah Aziz and Nik Mohd Ruiz Razy. 2017. Urban revitalisation for a city's soul: The case of Kampong Bharu. Kajian Malaysia 35(Supp.1): 119-140. https://doi.org/10.21315/km2017.35.Supp.1.7

To link to this article: https://doi.org/10.21315/km2017.35.Supp.1.7

\begin{abstract}
It is an accepted dogma by urban planning gurus that livable and sustainable cities, neighbourhoods and communities are those with souls that differ according to the communities' socio-cultural, economic, political and physical environments and perspectives. The soul of a city is in its people. This article presents findings from a study on the revitalisation of Kampong Bharu. Being only a conceptual study, the findings are only based on literature review, observations through walkabouts and drive-throughs, and interviews with custodians and major stakeholders. The article presents the results of the conceptual study: the concept of a city's soul in urban planning, the urban village concept, history and characteristics of Kampong Bharu the urban village, manifestations of its soul. The article will also present key issues in revitalising Kampong Bharu that is, custodians, mandates and institutional arrangement, heritage-led development, and a brief assessment of actions in urban heritage conservation and revitalising of Kampong Bharu's soul. The study concludes by supporting the move to revitalise Kampong Bharu and its soul. However, a deeper research is recommended to untangle the conundrum created by its legal and institutional arrangements; establishing a formal definition of Kampong Bharu's soul; the development of a set of criteria
\end{abstract}


for planning a heritage-led development; and cataloging tangible and intangible Malay cultural elements in Kampong Bharu.

Keywords: urban revitalisation, a city's soul, the Malay soul, heritage-led development, urban redevelopment

\section{INTRODUCTION}

It is an accepted dogma by urban planning gurus that livable and sustainable cities, neighbourhoods and communities are those with souls that differ according to the communities' socio-cultural-economic-political-physical environments and perspectives. When urban planning was still termed as physical planning, the planning guru Faludi described the planning professional's sphere of activity as "... the planning of the unified development of urban communities and their environs and of states, regions, and the nation" (Faludi, 1973: 43). Faludi's exponent Wickham emphasised that "Integral to the spirit of the good city is its public and social life, its zest and gaiety and the capacity for intermingling...a place of exuberance and exaltatation of the human spirit, a place for celebration and public 'happenings', for rich and easy encounter, for relaxation and enjoyment. It must not be simply functional and utalitarian" (Wickham, 1987 in Girardet, 2004: 153).

Today community life is commonly referred to as the "city's soul" which can be many things, depending on which part of a community one wants to talk about (Sandow, 2014). The city's soul is in its street's physical pattern, experiences, history, tangible and intangible artifacts, market, eateries, activities and street food (Wong, 2016). The soul of a city is what connects people, traditions, ideas, markets, communities, religions, political ideologies, economic barriers, family systems and relationships (Emerson, n.d.). The soul of a city is in its people (Saulter, 2011). Cities do not become what they are solely because of urban design. Without diversity of age, income, ethnicity, occupation and ideas, cities will lack the soul that make them places where people want to be, i.e. the city is about the community.

The soul of a new city is moulded by the combination of city design, urban fabric, facilities, the population(s) it attracts and activities and cultures of the new population-mix. Existing cities and neighbourhoods/villages, on the other hand, already have souls that were formed by people who had lived in those areas for over 100 years. Tangible cultural elements are displayed in building designs and other artifacts, while intangible cultural elements are in their local population's customs and practices, language, way of life, forms of livelihood. Heritage cities, particularly urban villages, face pressure from modernisation and redevelopment. Therefore, urban development or redevelopment of existing cities/settlements is 
best done through urban conservation that includes regeneration or revitalisation, by restoring the culture of the prestigious past while improving the lifestyle of its present and future population. Cultural heritage sites are only significant when their original communities remain (Shahrul Yani, Hasnizan and Elma Dewiyana, 2013).

Cities are expressions of culture. Urbino, Italy, a UNESCO's world heritage city, is worthy of mention, being a success story of cultural conservation. After the great economic crisis of the 14th century in Europe, there were goals for urban transformation to "trigger new impetus" to cities. The ambitious propositions of a new culture (visually and aesthetically) during the Renaissance and the onset of Humanism could be applied to an enhancement of Urbino's already defined urban layout. However, Urbino managed to resist it while enhancing its economic base. It is the only place in the world where such great cultural efforts have been exercised for a city of such limited spatial dimensions. Urbino covers only 35 hectares and never had a population of over 7,000 inhabitants, thus perhaps the only city in the world that has succeeded in becoming a city of worldwide cultural interest without exeeding the urban threshold of 10,000 inhabitants. The main principle is conserving culture for its role for life in general. While today culture is often attributed to values that tend to be sectorial and segmented in the past, culture had a founding value that binds it tightly to political practices and, in preceding political policies, depends on that strange word which authors of the Renaissance called virtue. Virtue was the incentive by which things were accomplished (Benevolo, 2002).

This article presents findings from a conceptual study on the proposed revitalisation of Kampong Bharu as a "Centre of Malay Culture" (Kampong Bharu Development Corporation, 2014). It is noted that "Kampong Bharu" is spelt using the old spelling and not the new spelling of "Kampung Baru". This is consistent with the decision by Kuala Lumpur City Hall to retain the old spelling for this Malay heritage enclave in the heart of Kuala Lumpur. The original spelling of "Kampong Bharu" is used in Act 733, Kampong Bharu Development Corporation Act 2011 that was established "to make provisions relating to the development of Kampong Bharu, and to provide for consequential and incidental matters" (Malaysia Act, 733). "Kampong Bharu" is used to describe the area in the Kuala Lumpur Structure Plan 2020, the Draft Kuala Lumpur City Plan 2020, Kampong Bharu Comprehensive Development Master Plan (2014) and Kuala Lumpur City Hall (2016).

Being a conceptual study, the findings are only based on literature review, observations through walkabouts and drive-throughs, and interviews with representatives of Kampong Bharu's custodians i.e. the Chief Executive Officer of Kampong Bharu Development Corporation (KBDC), Secretary of the Malay Agricultural Settlement (M.A.S.) of Kampong Bharu and representatives 
of stakeholders i.e. landowners cum developers. The methodology is considered adequate because it was only for a conceptual study that is intended to precede an indepth research on key findings from this initial phase. Walkabouts, drive throughs and interviews within a period of one month are sufficient to get the feel of Kampong Bharu's soul. This article briefly describes the origins of the concepts of the city's soul in urban planning, and the concept of urban village that is used to describe Kampong Bharu. It then describes and discusses Kampong Bharu's history, its soul, KBCDP's redevelopment proposal and the Kampong Bharu City Centre (KBCC) Master Plan 2016. The article concludes with several key issues and recommendations for a further in-depth research on Kampong Bharu, based on the key issues that are highlighted in this article.

\section{MANIFESTATIONS OF KAMPONG BHARU'S SOUL}

Kampong Bharu is located in the centre of Kuala Lumpur City Centre (Figure 1) i.e. it is at the heart of Kuala Lumpur. It is situated next to Kuala Lumpur's mega development areas (high-rise modern developments of KLCC, along Jalan Tun Ismail, Jalan Ampang and Jalan Bukit Bintang). The marked socio-economicphysical development contrasts between the urban fabric and landscape of these modern areas and those of Kampong Bharu, thus necessitating a revitalisation of the urban village to be at par, if not better than its towering neighbours.

Kampong Bharu consists of mostly single and two storey buildings, currently dwarfed by modern world class skyscrapers surrounding it. Mega developments along Jalan Ampang, Jalan Bukit Bintang, Jalan Tun Ismail and the Golden Triangle contrast with the ailing vernacular Malay houses, interspersed with dilapidated traditional Malay houses, modern four-storey institutional and limited commercial activities and roadside small businesses in Kampong Bharu. Figure 2 shows Kampong Bharu, the urban village, nestled in the midst of world class modern developments.

\section{Kampong Bharu: The Urban Village}

In urban planning an urban village refers to a community of people or human settlement that is relatively clustered but smaller than a town. It denotes a community or settlement that is small and subsistence-based, local, rural in characteristics and fundamentally traditional, particularly tied to some socio-cultural system and values. They are communities that are closely tied to cultural and traditional values and are situated and co-exist within metropolitan areas. Urban villages are rural-like enclaves inside large cities, characterised by high building densities, poor building quality, irregular streets and open sewage (Sharifah Mariam, 2012). Physically 


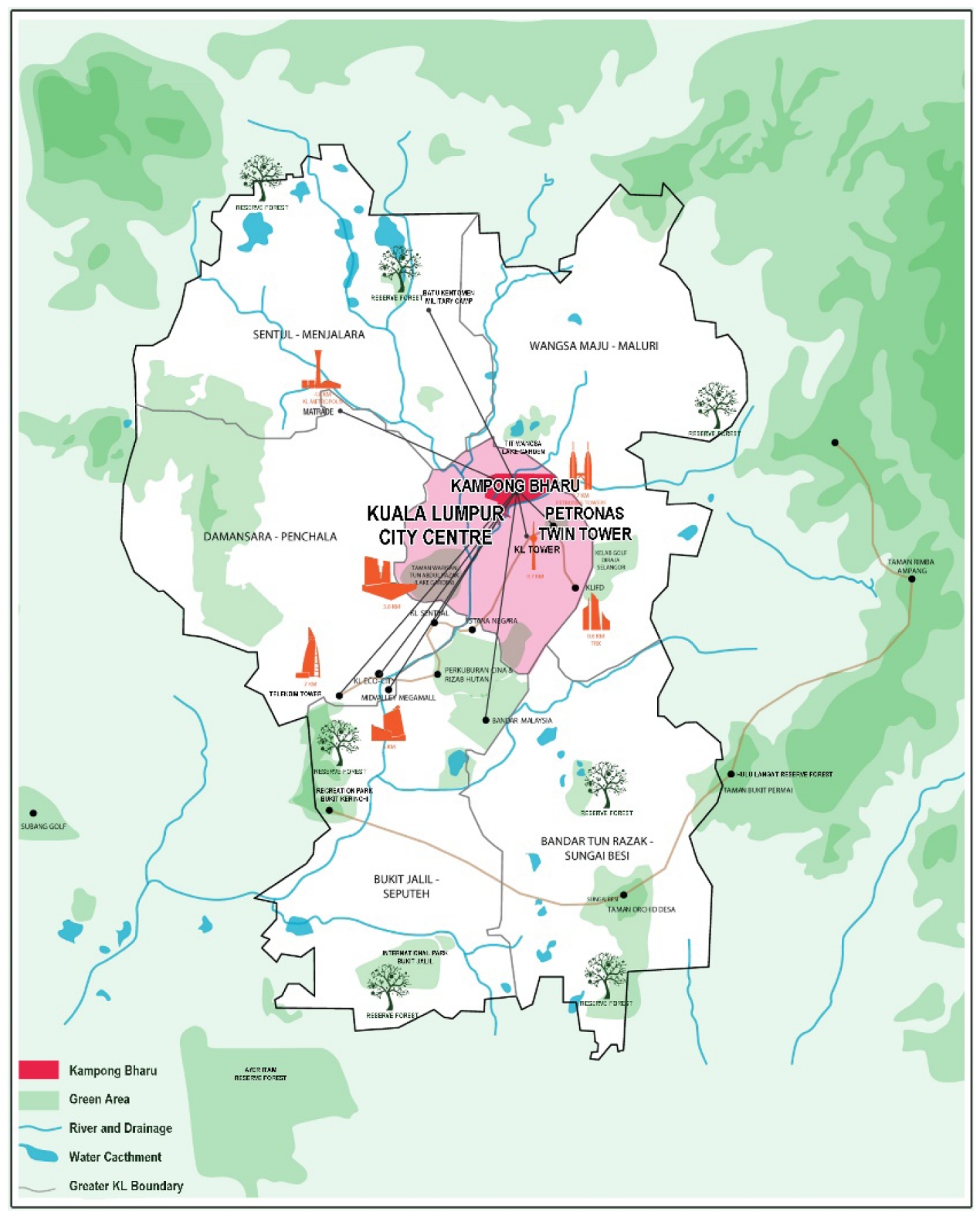

Figure 1: Kampong Bharu's strategic location at the city centre of Kuala Lumpur by Nik Ruiz Razy, 2017. 


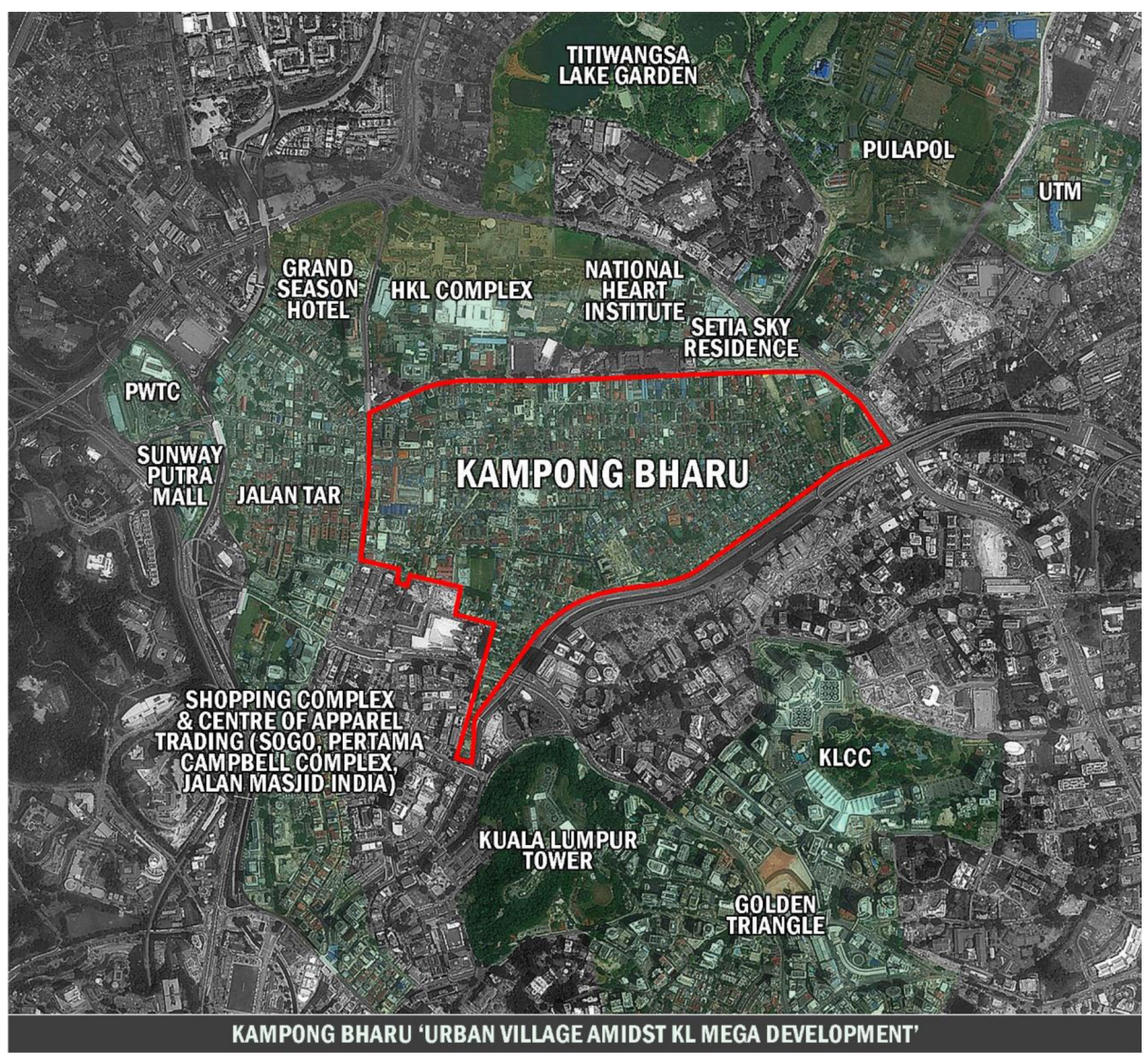

Figure 2: Kampong Bharu urban village amidst KL mega developments by Nik Ruiz Razy, 2017

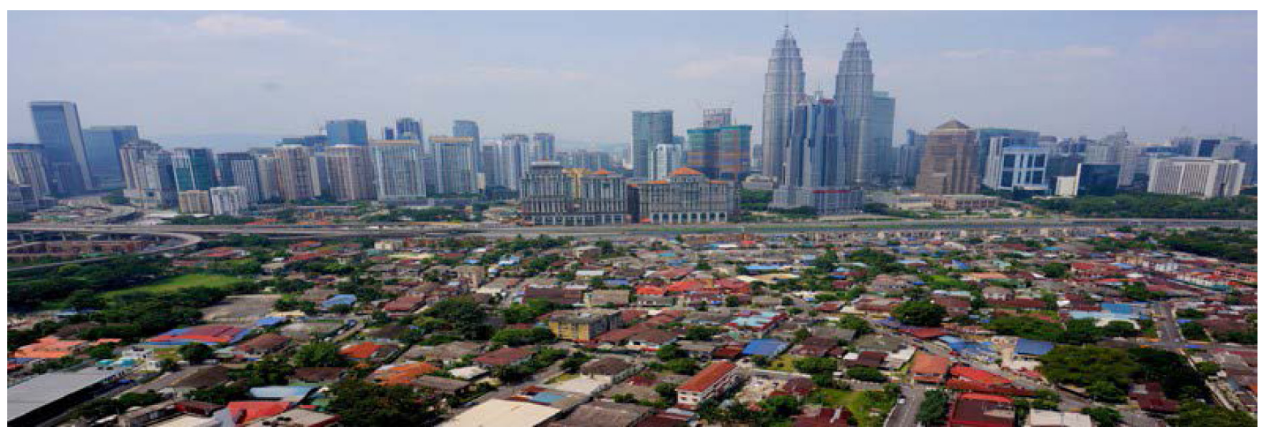

Figure 3: 1st World Golden Triangle and mega developments next to $3^{\text {rd }}$ World Kampong Bharu Urban Village in the heart of Kuala Lumpur.

Source: Kampong Bharu Comprehensive Development Master Plan (2014). 
these rural-like settlements are surrounded and overshadowed by skyscrapers, transportation infrastructures and other modern urban constructions. Kampong Bharu fits into these characteristics and therefore can be rightfully categorised as an urban village (Figures 3 and 4).

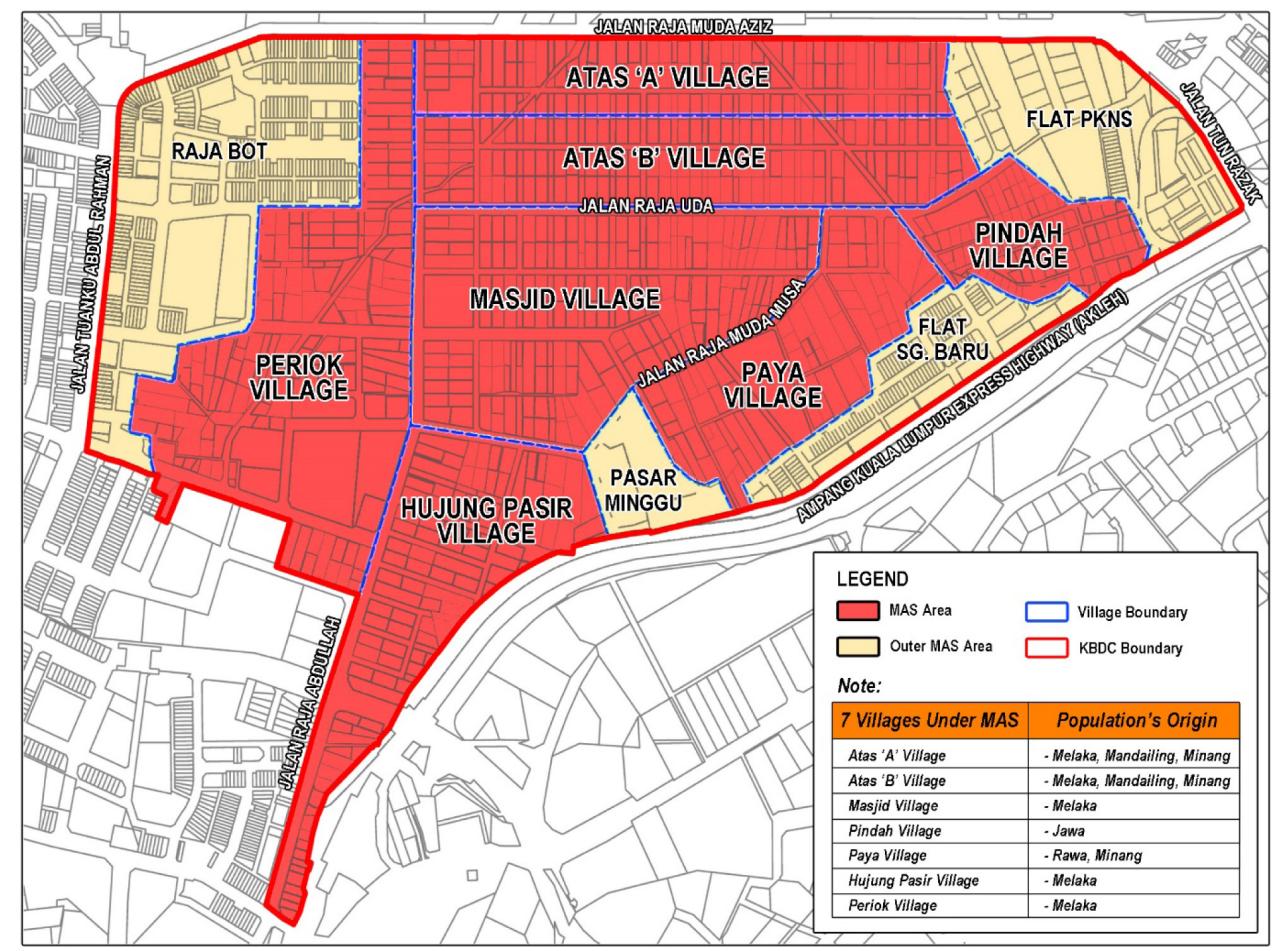

Figure 4: Kampong Bharu Malay Agriculture Settlement (MAS) villages and non-MAS sub-areas.

Source: Malay Agricultural Settlement (M.A.S.) Board, 2017.

Due to its strategic location in the Kuala Lumpur city centre, Kampong Bharu has experienced development pressure and has undergone ad hoc developments over the years. It is currently a paradox of relative tranquility and chaotic development, although it is still in the originally planned colonial-style neat grid-layout of a planned traditional Malay village. However, it is presently relatively retarded in its development, with poor roads, haphazard urban design and infrastructure. The straightening of the Klang River that runs along side it in the 1960 s contributed to its vulnerability to floods. Its physical image worsens after the construction of walls along the riverside which separated Kampong Bharu physically from Jalan Ampang, KLCC and the Light Rail Transit. Rental is relatively cheap, and hence attracts the poor and transient who come from rural 
areas, including foreigners, to make a living in the city. Deplorable living environments often breed social problems such as crime, drug addiction, alcoholism and even prostitution (Sharifah Mariam, 2012).

\section{What is Kampong Bharu's Soul?}

As a Malay Agricultural Settlement (M.A.S.) that was gazetted in 1900, Kampong Bharu has seven villages with population of different origins: Atas A Village and Atas B Village (settlers of Melaka, Mandeling and Minang origins), Masjid Village (settlers of Melaka origin), Pindah Village (settlers of Java origin), Paya Village (settlers of Rawa and Minang origins), Hujung Pasir Village (people of Melaka origin) and Periok Village (people of Melaka origin), totalling 223 acres. The Outer M.A.S. lands cover 84 acres (Raja Bot Village, Perbadanan Kemajuan Negeri Selangor (PKNS) Flat, Pasar Minggu/Weekly Market, Kampong Bharu Flat), making a total of 307 acres (123 hectares) (Figure 4).

The pioneer settlers of Kampong Bharu under M.A.S. were mainly of Mandeling, Minang, Jawa, Rawa and Melaka origins. The non-M.A.S. areas had settlers mainly from Selangor, because before the Federal Territory, the areas were under the state of Selangor. Under the M.A.S. rule, settlers must be Malays, regardless of origins. Rationally, therefore Kampong Bharu's soul is everything that constitute the tangible and intangible Malay cultural heritage. If Kampong Bharu is to be sustained as a Malay Cultural Centre, then the elements of historical and cultural heritage of the Malays, which form the Malay soul, must be conserved sustainably. The Malay soul is manifested in Rumah Limas (Traditional Malay house built in 1913), Master Mat's House (built in 1921), Kelab Sultan Sulaiman Building (the venue of the first meeting of United Malays National Organisation (UMNO) that represents the history of the Malay people's political struggle, the Malay Food Street (Jalan Raja Muda), Masjid Jamek Kampong Bharu, Evening Street Bazaar (Jalan Raja Alang), small Malay roadside businesses (tailor, songkok makers, barbers, cobblers, coffee shops, eateries, Malay traditional cakes, and the famous Bubur Lambok Kampong Bharu (the special spicy porridge that is cooked and distributed to people from Masjid Jamek during the fasting month of Ramadhan). Intangible Malay heritage in Kampong Bharu includes language and relaxed way of life, friendliness and accommodative hospitality to visitors, the kampong way of life that is part of being a close-knit community in which its members are cooperative, helpful and supportive of each other like being family members.

Kampong Bharu is rich in history, having gone through several significant events since its inception in 1900. According to the Secretary of the M.A.S. Board, "This is where everything started" ("Di sini segalanya bermula"). Table 1 presents the chronology of most significant events in Kampong Bharu. 
Table 1: Chronology of most significant events in Kampong Bharu

\begin{tabular}{|c|c|}
\hline Year & Events \\
\hline \multicolumn{2}{|r|}{ 1900-1940 under the British Government } \\
\hline 1899 & $\begin{array}{l}\text { The 1st Resident General of the Federated Malay States, Sir Frank Antheistance } \\
\text { Swettenham and the Selangor British Resident, John Pickersgill Rodger expressed } \\
\text { the intention to establish a Malay settlement in Kuala Lumpur. }\end{array}$ \\
\hline 1900 & $\begin{array}{l}\text { The Malay Agricultural Settlement (M.A.S) was formed under Selangor Government } \\
\text { Gazette No. 20, Section } 6 \text { of the Land Rule 1897, under the administration of the } \\
\text { M.A.S Board. }\end{array}$ \\
\hline 1901 & Started padi cultivation on 4 acres of land by 16 planters. \\
\hline 1902 & Padi planting was declared unsuitable in Kampong Bharu. \\
\hline 1914 & The first Malay Girls school in Kampong Bharu. \\
\hline 1914 & Settlers of Kg. Periok and Kg. Hujung Pasir were given land grants. \\
\hline 1927 & $\begin{array}{l}\text { Street lighting and roadside piped water was first started at Hale Road and Princess } \\
\text { Road. }\end{array}$ \\
\hline
\end{tabular}

1940-1945 under the Japanese Government

1942 The Japanese Army occupied Kuala Lumpur.

1942-1945 The Deputy Chairmen of M.A.S were Japanese.

Minutes of meetings were written in Japanese and Malay.

\begin{tabular}{|c|c|}
\hline \multicolumn{2}{|r|}{ 1946-2015 + Seeds of Independence and Modernisation } \\
\hline 1946 & $\begin{array}{l}\text { 1-4 Mac. Gathering of the Malayan Congress at Kelab Sultan Sulaiman, headed by } \\
\text { Dato' Onn Jaafar. }\end{array}$ \\
\hline 1955 & The first General Election of Malaya at Kelab Sultan Sulaiman. \\
\hline 1957 & $\begin{array}{l}\text { Masjid Jamek Kampong Bharu was completed, funded by the Selangor Governemt } \\
\text { and the settlers. }\end{array}$ \\
\hline 1966 & $\begin{array}{l}\text { Selangor State Development Corporation (Perbadanan Kemajuan Negeri Selangor- } \\
\text { PKNS) built Flat PKNS. }\end{array}$ \\
\hline 1969 & May 13th Racial Riots started at Princess Road (Jalan Raja Muda Abdul Aziz). \\
\hline 1975 & $\begin{array}{l}\text { DBKL prepared a development plan for land amalgamation towards feasible } \\
\text { comprehensive development. The plan was not implemented. }\end{array}$ \\
\hline 1985 & $\begin{array}{l}\text { DBKL proposed for individual plot developments with a rolling fund of RM5 million. } \\
\text { The move was unsuccessful. }\end{array}$ \\
\hline 1991 & $\begin{array}{l}\text { Prime Minister instructed DBKL to take over a part of Kampong Bharu for } \\
\text { comprehensive development within } 4 \text { years under the Kampong Bharu Development } \\
\text { Council. The move was unsuccessful. }\end{array}$ \\
\hline 2012 & $\begin{array}{l}\text { Kampong Bharu Development Board (Perbadanan Pembangunan Kampong Bharu) } \\
\text { was formed for comprehensive development of Kampong Bharu. }\end{array}$ \\
\hline 2015 & $\begin{array}{l}\text { Kampong Bharu Comprehensive Development Plan } 2035 \text { was announced. The Urban } \\
\text { Development Authority (UDA) project, UDA Legasi was launced at the site of the } \\
\text { historic Pasar Minggu (Weekly Market). }\end{array}$ \\
\hline
\end{tabular}

Source: Malay Agricultural Settlement (M.A.S.) Board, 2017. 


\section{KEY ISSUES IN REVITALISING KAMPONG BHARU}

This study has identified three key issues that must be resolved before Kampong Bharu can be revitalised: (a) Legal Custodians, Mandates and Institutional Arrangements; (b) Heritage Conservation-Led Development; and (c) Sustaining the Malay Soul.

\section{Legal Custodians Mandates and Institutional Arrangements}

Kampong Bharu has a unique situation. There are three key custodians who all have a stake in Kampong Bharu, derived from separate statutory instruments. This raises a rather complicated issue as to which custodian actually holds and can carry out all that is necessary to ensure that history and heritage i.e. the soul of Kampong Bharu is conserved. The three legal custodians are: (1) Management Board of the M.A.S.; (2) City Hall of Kuala Lumpur; and (3) Kampong Bharu Development Corporation.

\section{Management Board of the M.A.S. under the Selangor Sultanate}

In 1900, an area was carved out in the state of Selangor under Section 6 of the Land Enactment of 1897, published in the Selangor State Government Gazette No. 20, as a M.A.S. area with a primary purpose of providing a settlement, opportunities for Malays to carry out agricultural activities, as well as foster cultural and traditional trade or artisanal skills (Arkib Negara Malaysia, 1900). In order to manage the area, a Management Board was set up, where the Crown Prince of Selangor served as Chair, and the Acting British Resident of Selangor, D. G. Campbell, as ViceChair. The appointment of the officers of the Board was under the purview of the Acting British Resident, H. Conway Belfield (Arkib Negara Malaysia, 1900). The Board was given the power to approve the distribution of residential lots not exceeding 0.8 hectares in size per applicant (Arkib Negara Malaysia, 1900), with further powers to control how land was developed, including aspects relating to cleanliness. Registration of settlers and transfers are recorded by the Board, in a Register that details transactions as well as transfers according to syariah law (Arkib Negara Malaysia, 1900).

Five decades later, the Malay Agricultural Settlement (Kuala Lumpur) Rules 1951, ("the Rules") was gazetted on 18 January 1951. The 1951 Rules updated the previous gazette, detailing the rules for the occupation and management of the Settlement, which falls under the management and control of the Board of Management of the Settlement. The M.A.S. Board members were appointed by the Selangor Menteri Besar (Rule 3), replacing the power vested in the British Resident in the 1900 Gazette No. 20. Rule 4 provides the Board with power to 
make by-laws not inconsistent with the Rules for effectual control and management of the Settlement, which is an implied condition of occupancy of any allotment in the Settlement. In addition, Rule 5 provides powers to the Board to set terms and conditions as they consider fit and proper, to impose. As the remit of what is "fit and proper" is not spelt out in detail, it could be read that this provides ample room for the Board to set terms and conditions so long as the purpose of the establishment of the Settlement is met. Based on Archive Records this included fostering culture.

The M.A.S. Board also maintains a Register that details the list of approved applicants, deletion and substitution of occupants, together with particulars relating to them and the allotments they are authorised to occupy (Rule 7). Under the Rules, only Malays are allowed to occupy an allotment, and a Malay person is taken to mean a person belonging to the Malay race, who habitually speaks the Malay language, professes the Muslim religion and practices Malay customs, and a person approved by the Board as "Malay" (Rule 2). Interestingly, this can be read to mean that the Board has a discretion to further determine whether an applicant is Malay, despite the four conditions set, giving them room to, in a way, shape the Malay culture or custom based on origin that will prevail in the Settlement. The occupant cannot, unless with expressed permission of the Board, permit any person other than a Malay to live in his house or any part of the allotment; and allow or permit his house to be sublet (Rule 11). The Board can order a registered occupant to vacate an allotment after three months' notice has been served on him, if they consider his conduct or mode of living to be in any way prejudicial to the object and well being to the Settlement or to other occupants thereof (Rule 13).

The Board also holds the power over determining the size of the allotment, which shall not exceed half an acre in size as well as limiting the number of allotments, i.e. one per applicant, unless it is passed down through inheritance or applied by way of expressed permission of the Menteri Besar communicated to the Board (Rule 5). In addition, the Board has control over building of dwelling houses which require the Board's approval that will require a plan being approved subject to prescribed conditions that may be imposed, connection to drainage, land maintenance and exclusion of cattle rearing (Rules 8 to 10).

The M.A.S. Board can also require the occupant to demolish any structure that was not erected according to approval or erected without approval (Rule 14), failing which the Board can require the occupant to vacate the allotment as per Rule 13. This again indicates the power the Board has to determine the mode of living in accordance to the purpose of the Settlement being established, rendering it powers to establish a "norm".

The Rules were complemented by a by-law, gazetted the same day, made under Rule 4 of the Rules for the Occupation and Management of the Malay Agricultural Settlement, Kampong Bharu, Kuala Lumpur (Gazette No. 66). The By-Law formalises the establishment of the Board and its functions, providing 
measures to address the maintenance of the Register, transmission of allotments, plans for building and extensions of houses, which attracts approval fees, and in the case of non-compliance, a fine. The Board, through this By-Law, has the power to control tenancy of houses rented with the approval of the Board, and 7\% of the annual rental shall be paid to the Board, in addition to the Board having the power to control rent as well as termination of tenancy. Any dispute arising between the occupant and tenant is to be brought to the Board, whose decision shall be final.

At the outset, the Rules and By Law would suggest that the M.A.S. Board has a wide authority on the Settlement, from determining who gets to occupy, and how allotments are occupied. They seem to have the power to shape the norm in the area, as they have control over the representation of the "way of living" in the area, i.e. the values to be upheld and the type of physical development that represents the purpose of the Settlement being established. This will need to be carefully studied, to see whether the Board has over the years established the criteria for development approval as well as orders to vacate, more so, in light of the Settlement area, becoming part of the Federal Territory with statutory instruments being put in place that may impact on the existing mandate, as it technically sits outside of Sultanate control.

\section{The Federal Capital, the Federal Territory of Kuala Lumpur and the City Hall of Kuala Lumpur}

In 1960, a law was gazetted proclaiming Kuala Lumpur as a Federal Capital, the Federal Capital Act 1960, and through the City of Kuala Lumpur Act 1971, the Municipality of the Federal Capital of Kuala Lumpur subsequently became known as the City of Kuala Lumpur. The City of Kuala Lumpur was later excised from the State of Selangor, with the amendment to the Constitution in 1973 via the Constitution (Amendment) (No. 2) Act 1973. The Federal Constitution now states that the territory of the State of Selangor shall exclude the Federal Territory of Kuala Lumpur.

The area of the Federal Territory of Kuala Lumpur as gazetted under Gazette Plan No. 383, now falls within the Federal Capital Act 1960 (FCA 1960), under the planning control of the Federal Territory (Planning) Act 1982 and the Federal Territory Land Rules 1975. The Commissioner of the City of Kuala Lumpur or popularly known as the Dewan Bandaraya of Kuala Lumpur (DBKL), a body corporate formed under Section 5 of the FCA 1960, serves as the local government for the territory, and exercises the powers under the following laws:

1. Federal Capital Act 1960

2. City of Kuala Lumpur Act 1971

3. Local Government Act 1976 
4. Street, Drainage and Building Act 1974

5. Federal Territory (Planning) Act 1982

6. Road Transport Act 1987

7. Entertainment (Federal Territory of Kuala Lumpur) Act 1992

8. Hotel (Federal Territory of Kuala Lumpur) Act 2003

As far as land matters are concerned, the Federal Territory Land Rules 1975 (FT Land Rules), pursuant to the National Land Code 1965 (NLC) has been put into place to facilitate matters pertaining to land administration including land application, land premium, annual rents on land, temporary occupation of land, removal of rock material, permit to use air space, sale of federal land, and compounding of offences under the NLC. There is a special provision in the Rules pertaining to M.A.S., whereby rent collected has been spelt out in detail.

The Federal Territory (Planning) Act 1982 empowers the DBKL to prepare and implement development plans, which includes local plans or structure plans, within an extensive interpretation of development, which means carrying out of any building, engineering, mining, industrial, or other similar operation in, on, over, or under land, and includes any change in the use of any land or building or any part thereof, or the subdivision or amalgamation of lands. In addition, Section 64 provides for the power to make rules regulating development of land, design and appearance as well as protection of ancient monuments, and land and buildings of historic and/or of architectural interests.

\section{Kampong Bharu Development Corporation}

The Kampong Bharu Development Corporation (KBDC) was formed under the Kampong Bharu Development Corporation Act 2011, with powers to make provisions relating to the development of Kampong Bharu. The main function of the KBDC includes implementing policies, directions and strategies in accordance with plans prepared under the Federal Territory (Planning) Act 1982; serving as a principal coordinating body in relation to development, redevelopment and improvement of Kampong Bharu; promoting, stimulating, encouraging and facilitating economic, commercial and industrial growth; disseminating information on potential investments and promoting private sector investment; identifying and recommending strategies for provision of infrastructure for the maintenance and expansion of economy; managing and promoting sale of properties; addressing matters pertaining to submission for development; and maintaining records relating to the development of Kampong Bharu (Section 14). 
It would seem that the KBDC now serves to function with detailed provisions of powers, "taking over" the M.A.S. Board. Reference to Kampong Bharu being a settlement area is not made in the KBDC Act, nor does it refer to the M.A.S. Board that has functioned as a manager and administrator of the Settlement. In turn, it did not revoke the powers that already existed under the 1951 M.A.S. Rules and By-Laws. This would mean there are now three entities empowered by law to function as the administrators or custodians of Kampong Bharu.

Herein lies the conundrum. There are now three separate statutory instruments, empowering three separate entities: the Board of M.A.S. with general powers, DBKL with specific local government powers, and the KBDC with specific development powers. There is no specific statutory instrument that has been found that revokes the powers vested on the M.A.S. Board, and in fact, MAS is recognised under the FT Land Rules 1975.

The Federal Capital Act 1960, Section 16, states that any written law affecting the City, in force before the commencement of the Act shall, until amended or revoked by authority having power to do so under any other written law, continue in force. What needs to be carefully looked at is whether the M.A.S. falls within the Municipal Ordinance (Extended Application) Ordinance 1948 [F.M. 3 of 1948], in which there are provisions related to the City, where powers conferred upon the Ruler in Council of the State of Selangor would now be deemed conferred upon the Yang di-Pertuan Agong.

In addition, the FT Land Rules makes provisions for the collection of rent, which would mean allotment holders, may have to pay rent twice, once to the Board of M.A.S. and once to the Land Administrator. There is also a caveat, that can be read from the NLC at Section 4, which suggests that the NLC shall not affect the past operation of, or anything done under any previous land law or, so far as they relate to land, the provisions of any other law passed before the commencement of this Act in force relating to customary tenure; Malay reservations or Malay holdings; or sultanate lands.

There is a need to further study on whether or not M.A.S. falls within these exceptions. Custodianship and mandate to ensure that the heritage of Kampong Bharu can be properly addressed is critical, and this can only be done once this legal quagmire is resolved.

\section{Heritage-led Development for Kampong Bharu?}

As a historic traditional Malay enclave, an urban village that is economically behind its neighbours of 5-star high-rise buildings and infrastructure, Kampong Bharu needs socio-economic development and growth that will raise the income status and quality of life of its residents and land owners to be at par if not higher than that of its neighbours, while sustaining its soul by conserving its historical and cultural 
assets for future generations. The critical issue is how to manage the revitalisation of Kampong Bharu in such a way that respects the past while securing its long term future. DBKL, through KBDC, has planned to develop Kampong Bharu as a Malay Cultural Centre with modern high-rise buildings, among which will be sited several low rise buildings of traditional or vernacular Malay Muslim architecture. Existing traditional and vernacular Malay houses will be relocated to special development plots, for example in the planning of Kampong Warisan, where its traditional designs could be appreciated by residents and visitors (Figure 5). The question that was raised recurrently during the interviews was: is the proposed development by KBDC a heritage-led development?

The vision of the 2014 Kampong Bharu Comprehensive Development Master Plan 2035 is "Kampong Bharu as the Centre of Malay Culture and as a New Economic enclave for the City of Kuala Lumpur and Greater Kuala Lumpur" (Kampong Bharu Development Corporation, 2014: 1-2). Through this vision, "Kampong Bharu would be redeveloped as a modern precinct, meeting the standards of a high quality development competing with its surrounding area whilst incorporating Malay Islamic values and culture" (KBDC, 2014: 2-3). The mission is "To develop Kampong Bharu with inclusivity; by ensuring all land owners and their beneficiaries are together participating in the future development" (KBDC, 2014: 1-2). Anticipated challenges in achieving these are: (1) Land ownership status: absence of land titles on certain plots of land; ownership conflicts between land owners/beneficiaries; and land made as collateral with imposed restrictions; (2) Existing infrastructure and amenities' conditions: lack of or sub-standard existing infrastructure and community facilities to support large scale developments; small land sizes below 0.4 acres; absence of access or entry points to certain plots of land; and flood prone area; and (3) Implementation: legislation and financial constraints (KBDC, 2014: 1-19). The master plan is to transform the 115-year heritage urban village into a metropolis with $30 \%$ residential, $60 \%$ mixed development and $10 \%$ institutional and commercial development, with a population of 77,000 and 46,000 job opportunities by 2035. It is to be a "Malay Culture Centre" where 11 houses of heritage value would be relocated to "Kampong Warisan" and community-based structures (Masjid Jamek and Sultan Sulaiman Club Building) to be upgraded (Figure 6).

From the interviews, it seems that revitalising Kampong Bharu is welcomed in principle, but the master plan, and where and when development should start, was not agreed between the M.A.S. administration, KBDC and landowners. Kampong Masjid, where comprehensive development is identified to start, has a very high level of multiple ownerships and therefore not easy to implement, relative to Kampong Hujung Pasir. It was claimed that the master plan does not emphsise and focus on heritage and history, involves land acquisition whereby landowners will be dictated terms, and public consultation was not inclusive. This outraged many local 


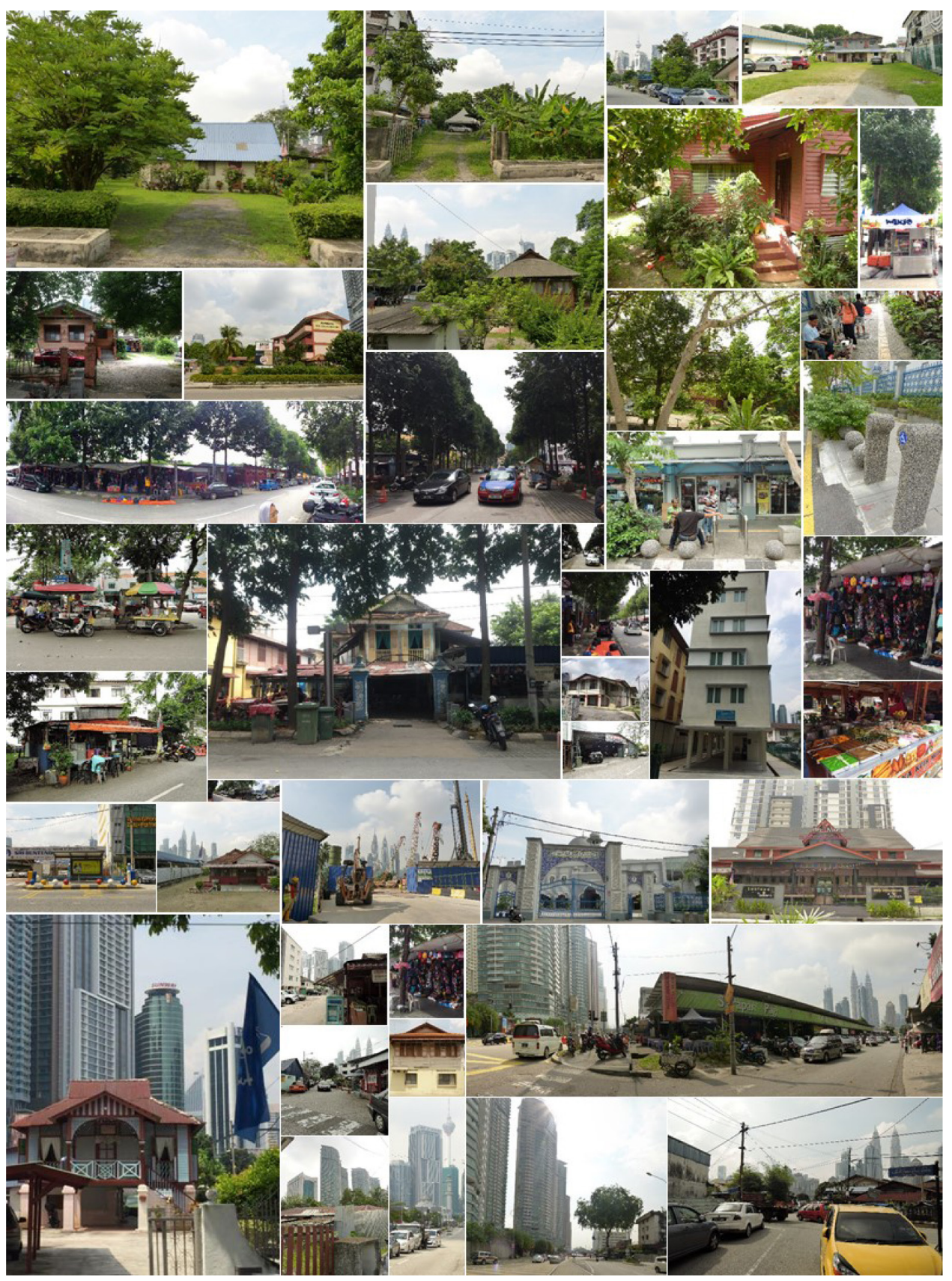

Figure 5: The villagescape of Kampong Bharu contrasts with the cityscape of adjacent areas.

Photos taken by Nik Mohd Ruiz Razy, Lukman Ramli and Muhammad Izzuddin Zafrol. 

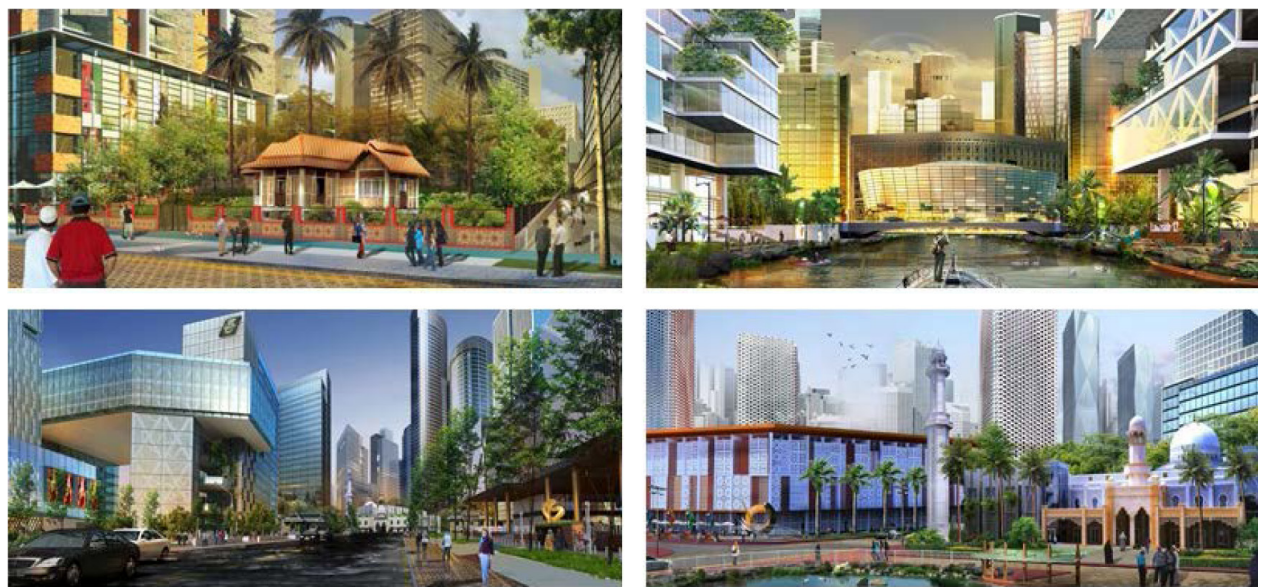

Figure 6: Blending Malay Muslim culture with modern architecture in the planning of Kampong Bharu.

Source : Kampong Bharu Comprehensive Development Master Plan (2014).

landowners. At an engagement session with landowners on 18.1.2015, as much as $22 \%$ were "happy" and 4\% were "inspired"; while at a session on 21.1.2015, a total of $61 \%$ were "angry", 19\% "sad" and 4\% "annoyed" (Gartland, 2015). Landowners interviewed in this study expressed disappointment with the amount offered to them for land acquisition, as the amount offered was too far below the market prices of adjacent lands. There was the feeling that they were "insulted" and treated as being "uneducated", which is contradictory to the claim made by one landowner that the Kampong Bharu Malays are the most educated Malays in the country. There seem to be poor coordination between Kampong Bharu Development Corporation (KBDC), M.A.S. administrators, Dewan Bandaraya Kuala Lumpur (DBKL) and landowners. The claims were that PKKB should focus on development instead of spending money and energy organising bazaars and festivals which are social obligations, which in fact is M.A.S. Board's responsibility. Landowners who were interviewed also did not agree with the proposal for Kampong Warisan, in particular with resiting of historial and traditional buildings. It was strongly felt that history should not be moved. Buildings must be left where they are, so that their souls remain.

Stakeholders who were interviewed support the existence of KBDC but feel that basic infrastructure must be sorted out first. Narrow roads that were meant for bullock carts must be upgraded for motorised vehicles in the whole area, instead of focusing only on areas for comprehensive development, such as the Kampong Bharu City Centre and Kampong Warisan. M.A.S. Administrators and landowners who were interviewed were of the opinion that the transformation process from a residential-focused Malay enclave towards a mixed residential-commercial- 
institutional development focus must be done in a gradual, incremental and viable manner, according to financial capabilities of landowners, and starting with lower plot ratios. This was suggested to be a more practical and affordable approach, instead of transformation via a massive leap that requires bigger financing, and may be unreachable. It was also suggested that for stronger commitment and ownership by stakeholders, landowners must be made partners of KBDC in development, instead of being mere consultees.

The design and modus operandi of the planning and implementation of Kampong Bharu redevelopment and revitalisation and opinions expressed by the M.A.S. administrators and landowners raised a very pertinent issue. Is the Kampong Bharu redevelopment project by KBDC heritage-led? Although guidelines for Malay Muslim architecture for buildings have been prepared by $\mathrm{KBDC}$, the interviewees expressed that it is not. If it is not, what criteria should be adopted in the planning and redevelopment of Kampong Bharu? The brief study conducted by the authors cannot answer these questions. There is a need for a further indepth study to come out with the preferred modus operandi for heritageled redevelopment of Kampong Bharu.

\section{Revitalising the Malay Soul in Kampong Bharu}

Interviewees were of the opinion that revitalising the Malay soul in Kampong Bharu is not an easy task, since most of the population are and would be transient population. Furthermore, the non-residential component of development would mean the inclusion of non-Malays in economic activities, either as operators or customers. According to the landowners who were interviewed, most successful and educated descendents from the original settlers have left the area. There is the issue of building skyscrapers in Kampong Bharu, since traditional Malay buildings cannot be taller than coconut trees. There was a strong opinion that the Malay soul is not merely in buildings with Muslim Malay architecture, because a building is only a shell for occupants. The Malay contents, i.e. the occupants and internal fittings are equally if not more important. The Malay soul is in the fine arts such as paintings and batik printing, songket weaving, silver and bronze handicrafts, kitemaking and art and crafts. Craftmen from other states - Kelantan was mentioned - could present a living heritage i.e. either through business activites or periodical live demonstrations. It was suggested that Karyaneka be a major player by establishing a centre in Kampong Bharu.

The general opinions of the landowners interviewed were that descendents of original settler groups are not the only representatives of "Malays". New settlers can include Malays from Nusantara. The Malay soul in Kampong Bharu must be seen as tangible (low-rise timber Malay architecture of both traditional and vernacular buildings, public and private building complements such as wakafs 
and handicrafts) and intangible cultural elements (languange, clothing styles, behaviour, dances). High rise buildings, if necessary for economic reasons, must be with Malay architechture and must be appropriately manifested. There must be places for outdoor and indoor congregations for social, religious and silat demonstrations and other cultural activities. There must be a mix of commercial outlets i.e. "kiosks", in market or bazaar settings for small businesses to provide the "village atmosphere" and the well known informal local eateries outlets that are synonymous with Malay trade, all with modern infrastructure and facilities, befitting of an enclave in the heart of a modern metropolis Kuala Lumpur. Traditional and vernacular buildings must be kept in their original sites to blend with new buildings so that their souls remain intact, thus sustaining the Kampong Bharu Malay soul.

\section{CONCLUSION AND RECOMMENDATIONS}

This article has put forward the importance of the welfare of past, present and future communities in urban planning, the significance of sustaining the communities' soul, and the need for cultural heritage conservation in modern developments. Urban redevelopment and revitalisation schemes must take into consideration the soul of the area and ensure that planning and implementation are heritage-led, so that the communities' soul is intact and enhanced in the new developments. Examination of the three custodians of Kampong Bharu i.e. the Malay Agriculture Settlement or M.A.S., Kuala Lumpur City Hall or Dewan Bandaraya Kuala Lumpur (DBKL), and Kampong Bharu Development Corporation (KBDC) has revealed a conumdrum in terms of their mandates and institutional arrangements, leading to dissatisfaction, even conflicts, in decisions made by each institution. Discussions with landowners revealed dissatifaction with the planning and implementation process being undertaken by KBDC.

The conceptual study by the authors cannot provide answers to all questions raised in the article. However, the study supports the revitalisation of Kampong Bharu but it must be accompanied by a revitalisation of its soul i.e. the Malay culture, both tangible and intangible elements. There is a need for a deeper research to untangle the conundrum created by its legal and institutional arrangements so that the roles and mandates of custodians are clearly stated. There is a need to formally define the Kampong Bharu soul as well as to develop a set of criteria for planning a heritage-led development. The criteria would serve Kampong Bharu's development as well as providing a lesson for urban conservation planners in general. The deeper research will also include cataloging tangible and intangible Malay culture in Kampong Bharu and for more inclusive community engagements in planning and development. 


\section{ACKNOWLEDGEMENTS}

The authors would like to express our deepest appreciation to all interviewees who had given their thoughts and time on this topic and to Kajian Malaysia for the opportunity to publish the findings of this initial study. A special tribute is made to the Governance and Education Heritage Conservation Group of Universiti Kebangsaan Malaysia for initiating the publication of this special edition of Kajian Malaysia.

\section{REFERENCES}

Arkib Negara Malaysia. 1900. Lembaga Pentadbir Kampung Baharu Kuala Lumpur. http://hids.arkib.gov.my/peristiwa/-/asset_publisher/WAhqbCYR9ww2/content/ lembaga-pentadbir-kampung-baharu-kuala-lumpur/ (accessed 31 March 2017).

Azira Aziz. 2008. The Kampung Baru issue. Malaysia Today. 24 May. http://www. malaysia-today.net/the-kampung-baru-issue/ (accessed 31 March 2017).

Bashiran Begum Mobarak Ali and Nor Asiah Mohamad. 2007. The "red-ink grants": The Malays and the land. IIUM Law Journal 15(2): 273-303. http://irep.iium. edu.my/7517/1/The_\%27Red-Ink_Grants\%27_The_Malays_and_the_Land.pdf (accessed 31 March 2017).

Benevolo, L. 2002. The city as an expression of culture: The case of 14th century urbina. In UNESCO World Heritage Centre, 2003. Partnerships for World Heritage Cities: Culture as a vector for sustainable urban development. World Heritage 2002 shared legacy, common responsibility associated workshops, Urbino, Pesaro Italy. 11-12 November.

Bruku, S. 2015. Community engagement in historical site protection: Lessons from the Elmina Castle Project in Ghana. Conservation and Management of Archaeological Sites 17(1): 67-76. https://doi.org/10.1179/1350503315Z.00000000094.

By-Laws made under Rule 4 of the Rules for the Occupation and Management of the Malay Agricultural settlement, Kampong Bharu, Kuala Lumpur. Selangor Government Gazette Notification 66.

City of Kuala Lumpur Act 1971. Kuala Lumpur: Percetakan Nasional Malaysia Berhad, Kuala Lumpur.

Emerson, M. n.d. Building the soul of a city. http://www.theworkofthepeople.com/bundle/ building-the-soul-of-a-city (accessed 31 March 2017).

Faludi, A. 1973. A reader in planning theory. Urban and regional planning series, Volume 5. Oxford, UK: Pergamon Press.

Federal Capital Act 1960 (Revised 1977). Kuala Lumpur: Percetakan Nasional Malaysia Berhad.

Federal Territory (Planning) Act 1982. Kuala Lumpur: Percetakan Nasional Malaysia Berhad.

Federal Territory of Kuala Lumpur Land Rule 1995. Kuala Lumpur: Percetakan Nasional Malaysia Berhad. 
Fujita, M. A. 2010. Forays into building identity: Kampung to kampong in the Kuala Lumpur metropolitan area. Journal of Architectural Education 63(2): 8-24. https://doi.org/10.1111/j.1531-314X.2010.01055.x.

Gartland, A. 2015. Master plan for Malay enclave outrages local landowners. https:// changingtimes.media/2015/01/18/master-plan-for-malay-enclave-outrages-locallandowners/ (accessed 31 March 2017).

Girardet, H. 2004. Cities, people, planet: Liveable cities for a sustainable world. US: Academy Press.

Hajah Sulasteri Abdul Hamid. 2012. Asal usul Kampong Bharu. Puspawangsa OctoberDecember: 17.

ICOMOS. 1999. The Burra Charter. The Australia ICOMOS Charter for Places of Cultural Significance. http://www.icomos.org/charters/burra1999_fre.pdf (accessed 31 March 2017).

Ismail Omar and Aminah Md Yusof. 2002. Indigenous land rights and dynamics of the land market in Kuala Lumpur, Malaysia. Habitat International 26(4): 507-521. https://doi.org/10.1016/S0197-3975(02)00024-3.

Ismail Omar, W. Djurjani and N. D. Prijono. 2009. Transaction cost analysis in redeveloping indigenous lands in Malaysia. Economia Seria Management 12(1): 21-40. http:// www.management.ase.ro/reveconomia/2009-1/3.pdf (accessed 31 March 2017).

Johana Hassan. 2008. A new Kampung Baharu with the old charm. http://www. christopherteh.com/publications/resources/MalaysianDigest.Com.pdf (accessed 31 March 2017).

Kampong Bharu Development Corporation (KBDC). 2014. Kampong Bharu Comprehensive Development Master Plan. Kuala Lumpur: Kampong Bharu Development Corporation.

. n.d. Garis panduan senibina Melayu Islam Kampong Bharu. 1st ed. Kuala Lumpur: Kampong Bharu Development Corporation.

Kampong Bharu Development Corporation Act 2011 (Act 733). Kuala Lumpur: Percetakan Nasional Malaysia Berhad.

Khairil Azhar Md. Yassin. 2009. Kampung Baru: Organizational study of an urban Malay settlement. Master diss., International Islamic University Malaysia.

Kuala Lumpur City Hall. 2016. Kuala Lumpur City Centre Comprehensive Development Master Plan 2016. Kuala Lumpur: DBKL.

2004. Kuala Lumpur structure plan 2020. Kuala Lumpur: Kuala Lumpur City Hall.

Lo' Lo' Dato' Hj. Mohd Ghazali. 2010. Sejarah penubuhan - Kampung Baharu Kuala Lumpur. http://docpearl.blogspot.my/2010/06/sejarah-penubuhan-kampungbaharu-kuala.html (accessed 31 March 2017).

Local Government Act 1976. Kuala Lumpur: Percetakan Nasional Malaysia Berhad.

Malay Agricultural Settlement (M.A.S.) Board. 2017. Seminar cetusan minda memperkasakan M.A.S. Kampong Bharu, Akar Beach Resort, Port Dickson. 31 March-2 April.

Mohd Hasrol Haffiz Aliasak and Mohd Farid Sa'ad. 2014. The 100 years of Malay Reserve Land in Peninsular Malaysia (1913-2013): An analysis of land size trend. Academia Journal UiTMT 3(1): 17-24. 
Norsidah Ujang and Faziawati Abdul Aziz. 2016. The Malay enclave of Kampong Bharu as a living tradition: A place of uncertainty. Environment-Behavior Proceedings Journal 1(2): 197-202. https://doi.org/10.21834/e-bpj.v1i2.269.

Nor Asiah Mohamad. 2007. Buying properties in Malaysia? Highlight on laws, policies and their implication on foreign land ownership. Journal of International Trade Law and Policy 6(2): 54-62. https://doi.org/10.1108/14770020780000556.

Nor Rasidah Hashim and Naziaty Mohd Yaacob. 2011. Urban landscape changes in Kampung Baru, Kuala Lumpur, from 1969 to 2004 as observed. Journal of Design and Built Environment 9(1): 49-58.

Sandow, G. 2014. The soul of a city. Arts Journal 24 November. https://www.artsjournal. com/sandow/2014/11/the-soul-of-a-city.html (accessed 31 March 2017).

Saulter, C. 2011. The soul of a city is in its people. http://grist.org/article/2011-01-24-thesoul-of-a-city-is-in-its-people/ (accessed 31 March 2017).

Selangor Rules 1951. The Malay Agricultural Settlement (Kuala Lumpur) Rules. Selangor Government Gazette Notification 50.

Sharifah Mariam Alhabshi. 2012. Kampung dalam bandar: Cabaran pembangunan semula. Akademika 82(2): 69-80.

.2010a. Surviving urban renewal programs: Case study of a traditional urban village in Kuala Lumpur. In Proceedings Seminar on National Resilience "Political Managements and Policies in Malaysia", eds. Mohd Azizuddin Mohd Sani and Abdul Rahman Abdul Aziz, 277-313. Sintok: Institute of Tun Dr. Mahathir Mohamad, Universiti Utara Malaysia.

2010b. Urban renewal of traditional settlements in Singapore and Malaysia: The cases of Geylang Serai and Kampung Bharu. Asian Survey 50(6): 1135-1161. http://repository.um.edu.my/86631/1/Geylang_KB_Alhabshi.pdf (accessed 31 March 2017). https://doi.org/10.1525/as.2010.50.6.1135.

Shahrul Yani Said, Hasnizan Aksah and Elma Dewiyana Ismail. 2013. Heritage conservation and regeneration of historic areas in Malaysia. Procedia, Social and Behavioral Sciences 105: 418-428. https://doi.org/10.1016/j.sbspro.2013.11.044.

Shaw, R. 2009. Sustainable eco-development of Kampong Bharu: A policy perspectives. Kuala Lumpur: Malay Agricultural Settlement and Kyoto University. http://www.preventionweb.net/files/12404_KBGPolicy1.pdf (accessed 31 March 2017).

Street, Drainage and Building Act 1974. Kuala Lumpur: Percetakan Nasional Malaysia Berhad.

Wong, A. 2016. Secubit rasa kampong. Going Places, March. https://issuu.com/spafaxmy/ docs/gp_mar_2016_binder (accessed 31 March 2017). 